UNIVERSIDADE DE SÃO PAULO

ESCOLA DE EDUCAÇÃO FÍSICA E ESPORTE

\title{
EFEITOS DO TREINAMENTO FÍSICO AERÓBIO SOBRE AS ALTERAÇÕES VASCULARES ESTRUTURAIS, MECÂNICAS E FUNCIONAIS DE RATOS ESPONTANEAMENTE HIPERTENSOS: MECANISMOS IMPLICADOS
}

Fernanda Roberta Roque Redondo

SÃO PAULO

2010 